\title{
30. CRETACEOUS AMMONITES (VALANGINIAN TO CENOMANIAN) FROM DEEP SEA DRILLING PROJECT CORES, SOUTHEASTERN GULF OF MEXICO ${ }^{1}$
}

\author{
Keith Young, The Department of Geological Sciences, The University of Texas at Austin, Austin, Texas
}

\begin{abstract}
Sites 535, 537, and 540, DSDP Leg 77, recovered ammonites. Core 537-4 yielded ammonites undiagnostic for dating. Core 540-44 yielded latest late Albian (Vraconian) ammonites. Three cores from Site 535 yielded ammonites producing good dates. Core 535-74 yielded Bochianites sp. indet., and Karakaschiceras sp. aff. $K$. victoriense; the date is either the early part of the late Valanginian or the late part of the early Valanginian. Scaphites n. sp. aff. S. simplex and Stomohamites sp. cf. S. virgulatus indicate the latest late Albian for Core 535-45, and Acompsoceras sp. dates Core 535-31 as middle Cenomanian.
\end{abstract}

\section{INTRODUCTION}

Early in 1981 (27 December 1980 to 30 January 1981), Leg 77 of the drilling program of Glomar Challenger was completed (Schlager et al., 1984). Cretaceous ammonites from cores at the three sites are reported herein.

From Leg 77 Sites 535, 537, and 540, several genera of Cretaceous ammonites were recovered. Only one level yielded ammonites at Site 537; it was in Sample 537-4-1, $1-3 \mathrm{~cm}$ ( $40 \mathrm{~m}$ sub-bottom depth). Two genera are represented. One of these is the long-ranged genus, Hypophylloceras; the other is probably a holcodiscid. Both specimens are extremely small, barely over $0.5 \mathrm{~cm}$ in greatest dimension, and identifications are not the best.

Ammonites were also recovered from one level at Site 540: Sample 540-44-2, 0-8 cm (440-450 m sub-bottom depth), with Turrilitoides sp. juv. aff. T. toucasi, and Sample 540-44-1, 76-78 cm, with Scaphites sp. n. aff. S. simplex.

The most complete set of ammonites is from Site 535 . Ammonites were first recovered from Core 535-31 (310 m sub-bottom depth) and were sporadically recovered to a depth of $790 \mathrm{~m}$ (Core 535-79). The forms recognized are listed in Table 1, but again, most of the specimens are extreme juveniles, difficult to compare to most of the much larger, similar forms described in the literature.

\section{STRATIGRAPHY}

With only isolated samples from cores, instead of continuous core, it was not possible for me to date the core throughout. However, with so few ammonites and with such juvenile specimens, it probably would not have been possible to do better had the entire core been available. The intervals in Table 2 contain datable ammonites. These dates do not often agree with, but do not depart greatly from, those of the site chapter (Sites 535 and 540), this volume.

${ }^{1}$ Buffler, R. T., Schlager, W., et al., Init. Repts. DSDP, 77: Washington (U.S. Govt. Printing Office).
Table 1. Ammonites from Site 535.

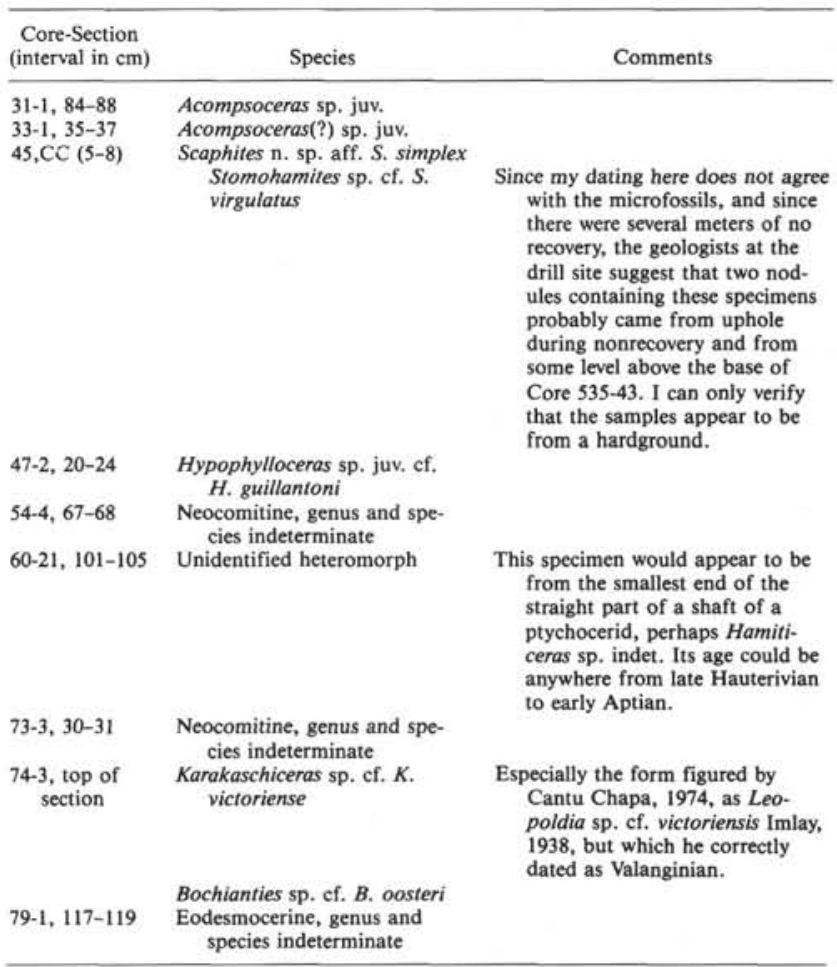

\section{TECHNIQUES}

Most of the fossils were either external molds or casts. An attempt to better prepare one fossil resulted in its complete destruction, so I refrained from trying to improve on the remainder. Rubber latex casts from the external molds were utitized for more natural photography.

\section{SYSTEMATIC PALEONTOLOGY}

Phylum MOLUUSCA

Class CEPHALOPODA

Order AMMONOIDEA

Suborder PHYLLOCERINA Arkell, 1950

Superfamily PHYLLOCERACEAE von Zittel, 1884

Family PHYLLOCERIDAE von Zittel, 1884

Genus HYPOPHYLLOCERAS Salfeld, 1924

Synonomy as in Wiedmann (1962, p. 139).

Type species: Phylloceras onoense Stanton, 1895. 
Table 2. Ages of samples with datable ammonites.

\begin{tabular}{|c|c|}
\hline $\begin{array}{l}\text { Hole- } \\
\text { Core-Section } \\
\text { (interval in cm) }\end{array}$ & Age \\
\hline $533-31-1,84-88$ & middle Cenomanian \\
\hline $535-33-1,35-37$ & middle Cenomanian(?) \\
\hline $535-45, \mathrm{CC}(0-8 \mathrm{~cm})$ & $\begin{array}{l}\text { late Albian, Stoliczkaia dispar and/or } \\
\text { Arrhaphoceras substuderi zones; geolo- } \\
\text { gists on board during drilling believe } \\
\text { that these are samples of rubble caved } \\
\text { from a level above the base of Core } \\
535-43 \text { during a long interval of no } \\
\text { recovery. }\end{array}$ \\
\hline $\begin{array}{l}535-74-3 \text {, top of } \\
\text { section }\end{array}$ & $\begin{array}{l}\text { early part of late Valanginian or late part of } \\
\text { early Valanginian, probably Saynoceras } \\
\text { verrucosum zone; this age is well within } \\
\text { the ranges of C. angustiforata (Perch- } \\
\text { Nielsen, 1979) and Calpionellopsis (Pop, } \\
\text { 1976, Dragaztan et al., 1975; Blauser } \\
\text { and McNulty, 1980; Chevalier et al., } \\
\text { 1975; Thierstein, 1975). }\end{array}$ \\
\hline $537-4-1,1-3$ & Neocomian(?) \\
\hline $540-44-2,0-8$ & $\begin{array}{l}\text { late Albian, Stoliczkaia dispar and/or } A \text {. } \\
\text { substuderi zones; the same level, bio- } \\
\text { stratigraphically, as } 535-45, C C, 5-8 \mathrm{~cm} \text {. }\end{array}$ \\
\hline
\end{tabular}

Hypophylloceras sp. juv. indet.

(Plate 1, Fig, 13)

Remarks. This small, incomplete specimen could belong to any of the species with rounded flanks or with flanks that diverge umbilicad. It is not more than a centimeter in greatest dimension, and, therefore, defies exact, specific identification.

Age. This fossil occurs with the juvenile that might be a holcodiscid, which is also not datable, but does agree with the earlier Cretaceous (Neocomian) determination by micropaleontology. WSA-18426 is from Sample $537-4-1,1-3 \mathrm{~cm}$.

\section{Hypophylloceras sp. cf. H. guillantoni (Collignon, 1932)} (Plate 1, Figs. 15, 17-18)

\section{$?=H$. androiavense (Besairie, 1936)}

Remarks. Hypophylloceras guillantoni (Collignon) is from the early part of the late Albian, and $H$. androiavense (Besairie) is from the late part of the middle Albian. They differ from the species group of $H$. velledae (Michelin) and the species group of $H$. seresitense (Pervinquière) in their more open umbilicus. In addition, species of the species group of $H$. velledae have more rounded flanks, whereas the flanks of the species group of $H$. serisetense are flattened, as are those of $H$. androiavense and $H$. guillantoni. WSA-18430 lacks the constrictions of Early Cretaceous species of Holcophylloceras (Thomel, 1980) and has a wider umbilicus than either Hypophylloceras ponticuli (Rousseau) or H. serum (Oppel) (Thomel, 1980).

Although micropaleontologic evidence suggests the sample is Bedoulian, the ammonites from Cores 535-46 and 535-47 do appear more like the Albian forms; it is possible that part of their shape is the result of sedimentary compaction.

Age. I do not feel that these forms are sufficiently well known to argue with the Bedoulian determination of the micropaleontologists. Many of the Early Cretaceous species of Hypophylloceras may have closely similar shapes, and no ornamentation is preserved on the forms illustrated herein. The genus ranges to below the Barremian. One specimen, WSA-18430, the better preserved, is from Sample 535-46-1, 95$100 \mathrm{~cm}$. The other, WSA-18429, is from Sample 535-47-2, 20-24 cm.

\footnotetext{
2 WSA numbers throughout this list and plate caption refer to museum numbers of specimens at the Texas Memorial Museum at The University of Texas, Austin, Texas.
}

\section{Suborder LYTOCERINA Hyatt, 1889 Superfamily LYTOCERACEAE Neumayr, 1875 Family LYTOCERIDAE Neumayr, 1875 Subfamily LYTOCERINAE Neumayr, 1875 Lytocerid, genus and species indeterminate} (Plate 1, Fig. 9)

Remarks. Whether the repressed zone around the ventrolateral area of this specimen is original or sedimentologic cannot be determined.

Age. WSA-18424 is from Sample 535-45,CC (5-8 cm) and immediately overlies fossils that are latest Albian.

\author{
Superfamily TURRILITACEAE Meek, 1876 \\ Family ANCYLOCERIDAE Meek, 1876 \\ Genus HAMITICERAS Anderson, 1938 \\ Hamiticeras (?) sp. indet. \\ (Plate 1, Fig. 4)
}

Remarks. Small specimens of species of Hamites, Protanisoceras, Hamulinites, and Hamiticeras may have reasonably straight shafts and no or little tuberculation, especially in the earlier growth stages (Thomel, 1964). Species of Hamulinites usually have costation at an oblique angle to the shaft. Accompanying microfossils indicate that this specimen is from below the Gargasian, and Hamiticeras sp. is therefore indicated.

Age. WSA-18432 is from Sample 535-60-21, 101-105 cm. Micropaleontology data indicate a late Hauterivian age.

\section{Family HAMITIDAE Hyatt, 1900 Genus STOMOHAMITES Breistroffer, 1940}

Type species: Hamites virgulatus Brongniart, 1822.

\section{Stomahamites sp. cf. S. virgulatus (Brongniart, 1822) (Plate 1, Fig. 3)}

Remarks. Small, straight fragments of shafts are not particularly diagnostic in the Hamitidae. Several late Albian species have ribs aligned more or less at right angles to the shaft. Most of these occur in the Stoliczkaia dispar Subzone (Spath, 1941). Some, like Stomahamites virgulatus (Brongniart, 1822), have ribs effacing over the dorsum; others, like $S$. venetzianus (Pictet in Pictet and Roux, 1847), show ribbing over the dorsum. Some are more finely costate as in S. duplicatus (Pictet and Campiche, 1861) and S. charpentieri (Pictet in Pictet and Roux, 1847). The present specimen in these features appears to be intermediate between $S$. duplicatus and $S$. venetzianus, but ribbing is more uneven than in those two species and is effacing over the dorsum as in S. virgulatus.

Age. WSA-18422, ascribed to Stomohamites sp. cf. $S$. virgulatus (Brongniart), is from Sample 535-45, CC (5-8 cm); it occurs with Scaphites n. sp. aff. S. simplex Jukes-Browne and most likely represents the Stoliczkaia dispar and/or Arrhaphoceras substuderi Subzones of the latest Albian (Vraconian).

\section{Family TURRILITIDAE Meek, 1876 Genus Turrilitoides Spath, 1923}

Type species: Turrilites hugardianus d'Orbigny, 1842

Turrilitoides sp. juv. cf. T. toucasi (Hébert and Munier-Chalmas, (Plate 1, Fig. 10)

Remarks. Turrilitoides is the late Albian genus of helicoid ammonites with continuous, relatively inornate ribbing. By its lack of tubercles it differs from Mariella, Plesioturrilites, Ostlingoceras, and Euturrilites. As Spath (1937, p. 529) points out, juvenile specimens of Turrilitoides toucasi (Hébert and Munier-Chalmas) cannot always be differentiated from those of $T$. hugardianus (d'Orbigny). The ribs of the present specimen do not seem as flexuous as those of the type of $T$. toucasi but straighter, as in T. hugardianus. Therefore, the identification is not tight. Spath insists that $T$. hugardianus does not range into the Stoliczkaia dispar Subzone (Spath, 1937, p. 529). The range of $T$. toucasi is not accurately known, but it is later late Albian. 
Age. Turrilitoides sp. juv. cf. T. toucasi (Hébert and MunierChalmas), WSA-18421, is from Sample 540-44-2, 0-8 cm, where it occurs with Scaphites n. sp. aff. S. simplex Jukes-Browne; it is latest Albian, perhaps Vraconian, Stoliczkaia dispar and/or Arrhaphoceras substuderi Subzones.

\section{Superfamily SCAPHITACEAE Meek, 1876 Family SCAPHITIDAE Meek, 1876 Subfamily SCAPHITINAE Meek, 1876 Genus Scaphites Parkinson, 1811}

Type species: Scaphites equalis J. Sowerby, 1814, subsequently designated by Meek (1876).

\section{Scaphites n. sp. aff. S. simplex Jukes-Browne, 1875} (Plate 1, Figs. 1-2, 5)

Remarks. Three specimens, two from Core 540-44, and the other from Core 535-45, represent a finely costate species of Scaphites. The lack of elongate, umbilical bullae and the nearly smooth flanks near the umbilicus relate the species to Scaphites simplex Jukes-Browne (1875). It differs from $S$. simplex in its denser and finer costation and in the even smoother flanks, whereas costation is only reduced on the flanks of $S$. simplex. Already there is a faint bundling of ribs on the umbilical flanks of specimens of $S$. simplex illustrated by Wiedmann (1962). This is not apparent in the specimens illustrated on Plate 1, where the umbilical half of the flank is almost smooth. S. hugardianus (d'Orbigny) of the early Cenomanian has ribs bifurcating from elongate umbilical bullae (Young, 1979).

Age. Scaphites simplex Jukes-Browne is typical of the late Albian. The lack of elongate, umbilical bullae indicates that the specimens from Sites 535 and 540 are also late Albian. The specimen referred to Scaphites simplex by Collignon (1964, plate 319 ) is recorded by him to be from the earliest Cenomanian. However, in Texas, where it was described as Scaphites hilli by Adkins and Winton (1920) (Wiedmann, 1962 , p. 213), it is latest Albian. One specimen (WSA-18423, Plate 1, Fig. 1) is from Sample 535-45,CC (5-8 cm). The other specimens (Plate 1, Figs. 2 and 5, respectively WSA-18434 and WSA-18416) are from Sample 540-44-1, 73-78 cm. They are latest Albian and probably represent the Stoliczkaia dispar and/or Arrhaphoceras substuderi Subzones. Furthermore, they render a fairly tight correlation of Core 53545 with Core 540-44.

\section{Scaphites sp. aff. $S$. simplex Jukes-Browne, 1875 (Plate 1, Fig. 8)}

Remarks. The specimen illustrated on Plate 1, Figure 8, is not described with those of Plate 1, Figures 1, 2, and 5, because the costation is different. The specimen is so finely lirate that the latex cast did not reproduce the ornamentation; it should have been photographed by the scanning electron microscope. It is lirate throughout the entire flank, unlike the specimen of Plate 1, Figure 1, which is smooth on the umbilical part of the flank. The lirae seldom bifurcate from the umbilicus but remain single completely to the umbilicus.

Age. Latest late Albian, from Sample 540-44-2, 20-22 cm. WSA18425 also represents the Stoliczkaia dispar and Arrhaphoceras substuderi Subzones.

\section{Suborder AMMONITINA Hyatt, 1889 \\ Superfamily PERISPHINCTACEAE Steinmann, 1890 \\ Family BERRIASELLIDAE Spath, 1922 \\ Subfamily NEOCOMITINAE Spath, 1924 \\ Genus Karakaschiceras Thieuloy, 1971}

Type species: Hoplites biassalensis Karakasch, 1889.

\section{Karakaschiceras sp. cf. K. victoriense (Imlay, 1938)}

(Plate 1, Figs. 12,16)

Remarks. The specimen illustrated on Plate 1, Figures 12 and 16, has the dense, prosiradiate, sometimes faintly sinuous ribbing of $\mathrm{Ka}$ rakaschiceras victoriense (Imlay, 1938). It is especially close to $K$. sp. cf. $K$. victoriense (Imlay) in Cantu Chapa (1976, plate 7, fig. 9, illustrated by him as Leopoldia sp. cf. victoriensis). The two figures on Plate 1 are of the same specimen but from opposite faces of a split core. Figure 12 shows the younger ornamentation, whereas Figure 16 shows the more mature ornamentation with ribbing reduced on the inner flanks as in $K$. victoriense (Imlay) and $K$. biassalense (Karakasch,
1889), which is the type species of Karakaschiceras Thieuloy (1971). $K$. victoriense (Imlay) may even be a synonym of $K$. biassalense (Karakasch). Leopoldia aenigmatica (Sayn, 1907, plate 3, figs. 26a-b) has similar ribbing but a different venter. The umbilicus in Cantu Chapa's specimen (Cantu Chapa, 1976) and in the specimen described herein is wider than the umbilici of $K$. biassalense (Karakasch) and $K$. victoriense (Imlay) but is similar in this respect to other species of Karakaschiceras illustrated by Kemper et al. (1981), from which it differs in its denser costation and reduced costation on the umilcead part of the flank. Without a visible venter assignment of most perisphinctaceans is never completely satisfactory.

Age. With this specimen, the immediate question was whether it was a species of Berriasella, Leopoldia, Karakaschiceras, or Thurmanniceras. Micropaleontologic evidence suggests that the sample is older than early Hauterivian; therefore, Leopoldia is eliminated, even though Trejo (1975) has reported Calpionellopsis ranging into the early Hauterivian. His report probably results from the occurrence of Calpionellopsis oblonga with Karakaschiceras victoriense, which as Leopoldia victoriensis Imlay had for 40 years been considered early Hauterivian, largely because of its assignment to Leopoldia. Any dating of early Hauterivian and an assignment of this specimen to Leopoldia are largely eliminated for Section 535-74-3. Micropaleontologists would prefer an assignment of this specimen to Berriasella, to agree with their $\mathrm{D}_{2}$ (Le Hégarat and Remane, 1968) assignment of the horizon to the late Berriasian; although, if the assignment to $D_{2}$ is on the basis of first appearances only, it could be suspect in this apparently thinned section represented by these samples from Site 535 .

The occurrence of a fragment of Bochianites, sp. cf. B. oosteri (Sarasin and Schöndelmayer, 1902), further restricts the assignment. Bochianites generally ranges from the late part of the early Valanginian through most of the late Valanginian. B. oosteri Sarasin and Schöndelmayer is stated to be Hauterivian by Patrulius and Avram (1976), but they also date Valanginian species of Karakaschiceras as Hauterivian by assigning them to the genus Leopoldia as do Drushtchitz and Kudryatseva (1960) and Drushtchitz and Gorbatschik (1979). The general range of Bochianites would be from the Thurmanniceras campylotoxum Zone through the Mortoniceras trinodosum Zone. However, Allemann, Wiedmann, and Grün (1975) show Bochianites baculoides to range well down into the Berriasian. Thieuloy (1971) showed Karakaschiceras to range through the late Valanginian, but later he (1973) suggested its range was restricted to the zones of $T$. campylotoxum (late early Valanginian) and Saynoceras verrucosum (early late Valanginian). I still believe the best date for the top of Section $535-74-3$, WSA-18428, is early late Valanginian, although late early Valanginian is not ruled out. Late Berriasian is a remote possibility.

Family BERRIASELLIDAE Spath, 1922 Subfamily NEOCOMITINAE Spath, 1924

Holcodiscid, genus and species indeterminate (Plate 1, Fig. 6)

Remarks. A small specimen, WSA-18427, is ribbed and has restrictions at a very early diameter. It could be a holcodiscid.

Age. WSA-18427 (Sample 537-4-1, 1-3 cm) is not diagnostic of age, but if a holcodiscid, would be Neocomian, an age in agreement with micropaleontologic data.

\section{Neocomitine, genus and species indeterminate (Plate 1, Fig. 19)}

Remarks. An involute, densely costate form with prosiradiate, straight ribs is not identifiable, partly because the ribs have been beaded by diagenesis.

Age. Micropaleontologic data suggest that WSA-18417 is late Valanginian to late Hauterivian. It is from Sample 535-54-4, 67-68 cm.

\section{Neocomitine, genus and species indeterminate} (Plate 1, Fig. 14)

Remarks. Just overlying the core with Karakaschiceras sp. cf. victoriense (Imlay) was a core with a fragment of a small ammonite with intercalation or bifurcation of ribbing similar to that of Kilianella or Odontodiscoceras, and with reduced or absence of umbilical tubercles. Taxonomic assignment is difficult.

Age. The most likely age for WSA-18418 would appear to be Valanginian. It is from Sample 535-73-3, 30-31 cm. 
Superfamily DESMOCERACEAE von Zittel, 1895

Family DESMOCERIDAE von Zittel, 1895 Subfamily EODESMOCERINAE Wright, 1955 Genus and species indeterminate

Remarks. A small specimen, not illustrated, could belong to the genus Barremites or one of its predecessors, probably a predecessor because it occurs below the level of the late Valanginian.

Age. WSA-18431 is from Sample 535-79-1, 117-119 cm. By itself it is undiagnostic for age.

\section{Superfamily ACANTHOCERACEAE Hyatt, 1900 Family ACANTHOCERIDAE Hyatt, 1900 Subfamily MANTELLICERINAE Hyatt, 1903 Genus Acompsoceras Hyatt, 1903}

Type species: Ammonites bochumensis Schlüter, 1871.

\section{Acompsoceras sp. juv.}

(Plate 1, Figs. 7,11)

Remarks. Acompsoceras is a distinctive genus, typically with a row of ventrolateral clavae and a row of umbilical bullae, sometimes connected with ribs, and with all ornamentation tending to efface on the adults. The specimen of Plate 1, Figure 11, is certainly a juvenile of the genus Acompsoceras, and if the greater effacement of the lateral ribs is the result of sedimentary compaction, this individual could belong to the type species, $A$. bochumense (Schlüter). The specimen of Figure 7 is so small it is unidentifiable. Because it occurs just below and looks like the inner whorls of the specimen of Figure 11, it is assumed to be the same species.

Age. Middle Cenomanian; Sample 535-31-1, 84-88 cm (WSA18419, Plate 1, Fig. 11) and Sample 535-33-1, 35-37 cm (WSA-18420, Plate 1, Fig. 7).

\section{ACKNOWLEDGMENTS}

The University Research Institute, The University of Texas at Austin, provided funds for study and illustration of the ammonites.

\section{REFERENCES}

Adkins, W. S., and Winton, W. M., 1920. Paleontological correlation of the Fredericksburg and Washita formations in north Texas. Univ. Texas Bull., 1945:1-128.

Allemann, F., Grün, W., and Wiedmann, J., 1975. The Berriasian of Caravaca (Prov. of Murcia) in the subbetic zone of Spain and its importance for defining this stage and the Jurassic-Cretaceous boundary. Colloque sur la limite Jurassique-Crétacé. Bur. Rech. Geol. Min. Mem., 86:14-22.

Anderson, F. M., 1938. Upper Cretaceous of the Pacific Coast. Geol. Soc. Am. Mem., 71.

Arkell, W. J., 1950. A classification of the Jurassic ammonites. J. Paleontol., 28:354-364.

Besairie, H., 1936. Recherches géologiques à Madagascar, première suite, La géologie du Nord-Ouest. Mem. Acad. Malgache, 21: $1-259$.

Blauser, W. H., and McNulty, C. L., 1980. Calpionellids and nannoconids of the Taraises Formation (Early Cretaceous) in Santa Rosa Canyon, Sierra de Santa Rosa, Neuvo Leon, Mexico. Trans. Gulf Coast Assoc. Geol. Soc., 30:263-272.

Breistroffer, M., 1940. Revision des ammonites du Vraconian de Salazac (Gard) et considérations générales sur ce sous-étage Albien. Trav. Lab. Geol. Grenoble, 22:1-101.

Brongniart, A., 1822. In Cuvier, G., and Brongniart, A. (Eds.), Description Géologiques des Environs de Paris (3rd ed., 1935): Paris (Edmond D. Ocagne).

Cantu Chapa, A., 1976. El contacto Jurásico-Cretácico, le estratigrafía de Neocomiáno, el Hiato Hauteriviáno Superior-Eoceneo Inferior y las amonitas del Pozo Bejuco 6 (centro-Este de México). Soc. Geol. Mexicana Bol., 37:60-83.

Chevalier, J., Delfaud, J., Dubois, P., Jaffrezo, M., and Ricateau, R., 1975. Revision de la stratigraphie et de la paléogéographie des couches du passage Jurassique-Crétacé du Languedoc a l'Aquitaine. Colloque sur la Limite Jurassique-Crétacé. Bur. Rech. Geol. Min. Mem., 86:300-314.
Collignon, M., 1932. Ces Ammonites pyriteuses de l'Albian Supérieur du Mont Raynaud, Madagascar. Ann. Geol. Serv. Mines, 2:5-36. 1964. Atlas des fossiles caractéristiques de Madagascar (Ammonites). Fasicule 11, Cenomanien. Serv. Geol. Tananarive.

Dragaztan, O., Mutiu, R., and Vinogradow, C., 1975. Les zones micropaléontologiques Jurassique-Crétacé dans les Carpates orientales (Monts de Haghimas) et dans la plate-forme moesienne. Colloque sur la Limite Jurassique-Crétacé. Bur. Rech. Geol. Min. Mem., 86:188-203.

Drushtchitz, V. V., and Gorbatschik, T. N., 1979. Zonengliederung der Unteren Kreide der Südlichen UdSSR nach Ammoniten und Foraminiferen. In Wiedmann, J. (Ed.), Aspekte der Kreide Europas. Int. Union Geol. Sci., Ser. A, 6:107-116.

Drushtchitz, V. V., and Kudryatseva, M. N., 1960. Atlas of Lower Cretaceous Faunas of the Northern Caucasus and Crimea: Moscow (J. Sci. Tech. Branch of Petroleum and Mineral-Fuels Literature). [in Russian]

Hébert, E., and Munier-Chalmas, E. C. P. A., 1875. Appendice paléontologique. Description du terrain crétacé supérieur de Bassin d'Uchaux. Ann. Sci. Geol., 6:113-152.

Hyatt, A., 1889. Genesis of the Arietidae: Washington (Smithsonian Contrib. Knowledge 673).

1900. Cephalopoda. In von Zittel, K. A., (1st Eng. ed.) Textbook of Paleontology: London (MacMillan and Co., Ltd.), pp. 502-592.

1903. Pseudoceratites of the Cretaceous. Stanton, T. W. (Ed.), Washington, D.C. (U.S. Geol. Surv. Mon. 44).

Imlay, R. W., 1938. Ammonites of the Taraises formation of northern Mexico. Geol. Soc. Am. Bull., 49:539-602.

Jukes-Browne, A. J., 1875. On the relations of the Cambridge Gault and Greensand. Quart. Geol. Soc., 31:256-314.

Karakasch, N. I., 1889. Über einege Neokomalblagerungen in der Krim. Sber. Math. Naturwiss. Klasse Ost. Adak. Wiss., 97:428-438.

Kemper, E., Rawson, P. F., and Thieuloy, J. P., 1981. Ammonites of Tethyan ancestry in the early Lower Cretaceous of north-west Europe. Paleontology, 24(2):251-311.

Le Hégarat, G., and Remane, J., 1968. Tithonique supérieur et Berriasien de l'ardèche et de l'hérault: corrélation des ammonites et des calpionelles. Geobios, 1:7-69.

Meek, F. B., 1876. A report on the invertebrate Cretaceous fossils of the upper Missouri country. In Hayden, F. V. (Ed.), Report of the United States Geological Survey of the Territories (Vol. 9): Washington.

Neumayr, M., 1875. Die Ammoniten der Kreide und die Systematik der Ammonitiden. Zeitschr. Deutsch. Geol. Gesell., 27:854-892.

Oppel, A., 1863. Ueber jurassische Cephalopoden. Palaeont. Mitt. Musk. Bayer., 3:163-266.

d'Orbigny, A., 1840-1842. Paléontologie français: Terrains Crétacés, 1. Céphalopodes: Paris (Masson et Cie), 1840:1-120; 1841:121-430; 1842:431-662.

Parkinson, J., 1811. The Organic Remains of a Former World (Vol. 3): London.

Patrulius, D., and Avram, E., 1976. Les céphalopodes des couches de Carhaga (Tithonique Supérieur-Barrémien Inférieur). Inst. Geol. Geophys. Bucarest Mem., 24:153-201.

Perch-Nielsen, K., 1979. Calcareous nannofossils from the Cretaceous between the North Sea and the Mediterranean. In Wiedmann, J. (Ed.), Aspekte der Kreide Europas. Int. Union Geol. Sci., Ser. A, 6:223-272.

Pervinquière, L., 1907. Etudes de Paléontologie Tunisienne. I. Céphalopodes des Terrains Secondaires: Paris (Carte Geol. Tunisie).

Pictet, F. J., and Campiche, G., 1858-1864. Description des fossiles du terrain crétacé des environs de Ste.-Croix, pts. 1-2. Materiaux Paleont. Suisse. Ser. 2 (1858-1860), pp. 1-380 (pt. 1); Ser. 3 (1860-1864) (pt. 2).

Pictet, F. J., and Roux, W., 1847. Description des mollusques fossiles qui se trouvent dans les Grés Verts des environs de Gèneve. Mem. Soc. Phys. Hist. Nat. Geneve, 11(2):257-412.

Pop, G., 1976. Tithonian-Valanginian calpionellid zones from Cuba. Inst. Geol. Geophys. Bucarest, Dari de Seama, 62(3):237-266.

Salfeld, H., 1924. Bedeutung der Konservativestämme für die Strammesentwicklung der Ammonoideen: Leipzig (Max Weg).

Sarasin, C., and Schöndelmayer, C., 1902. Etude Monographique des ammonites du Crétacique inférieur de Chatel Saint-Denis. Mem. Soc. Paleont. Suisse, 29:95-195. 
Sayn, G., 1901-1907. Les ammonites pyrtieuses des Marnes valanginiennes du Sud-Est de la France. Mem. Soc. Geol. France Paleont., 9(1901):1-28; 15(1907):29-68.

Schlager, W., Buffler, R. T., and Shipboard Scientific Party, 1984. Deep Sea Drilling Project, Leg 77, Southeastern Gulf of Mexico. Geol. Soc. Am. Bull., 95:226-236.

Schlüter, C., 1871-1876. Dei Cephalopoden der oberen deutschen Kreide. Palaeontographica, 21(1871):1-24; 22(1872):25-120; 24(1876): 121-264.

Sowerby, J., 1812-1823. The Mineral Conchology of Great Britain (Vols. 1-4): London (J. Sowerby).

Spath, L. F., 1922. On Cretaceous Ammonoidea from Angola, collected by Prof. J. W. Gregory, D. Sc., F. R. S. Trans. R. Soc. Edinburgh, 43:91-160.

1923. Excursion to Folkestone, with notes on the zones of the Gault. Proc. Geol. Assoc., 34:70-76.

,1924. On the ammonites of the Speeton Clay and the subdivisions of the Neocomian. Geol. Mag., 1:73-89.

1937. A monograph of the Ammonoidea of the Gault: Part 12. Palaeontogr. Soc., 90:497-540.

, 1941. A monograph of the Ammonoidea of the Gault: Part 14. Palaeontogr. Soc., 95:609-668.

Stanton, T. W., 1895. Contributions to the Cretaceous paleontology of the Pacific Coast. The fauna of the Knoxville beds. U.S. Geol. Surv. Bull., 133.

Thierstein, H., 1975. Calcareous nannoplankton biostratigraphy at the Jurassic-Cretaceous boundary. Colloque sur la Limite JurassiqueCrétacé. Bur. Rech. Geol. Min. Mem., 86:84-94.
Thieuloy, J. P., 1971. Réflexions sur le genre Lyticoceras Hyatt, 1900 (Ammonoidea). C. R. Acad. Sci. Paris, D272:2297-2300.

1973. The occurrence and distribution of boreal ammonites from the Neocomian of southeast France (Tethyan Province). Geol. J. Liverpool, Spec. Issue, 5:289-302.

Thomel, G., 1964. Contribution a la connaissance des Céphalalopodes Crétacés du sud-est de la France: Note sur les ammonites déroullées du Crétacé inférieur Vocontienne. Soc. Geol. France, Mem., 101.

, 1980. Ammonites: Nice (Serre).

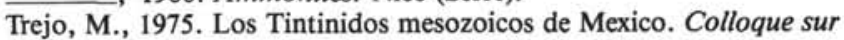
la Limite Jurassique-Crétacé. Bur. Rech. Geol. Min. Mem., 86: 95-104.

von Zittel, K. A., 1884. Cephalopoda. Handbuch der Palaeontologie: Munich, Leipzig (Oldenberg), pp. 329-522. 1895. Palaeozoologie. Grundzüge der Palaeontologie: $\mathrm{Mu}-$ nich, Leipzig (Oldenberg).

Wiedmann, J., 1962. Ammoniten aus der vascogotischen Kreide (Nordspanien): 1. Phylloceratina, Lytoceratina. Palaeontographica, 118: 119-237.

Wright, C. W., 1955. Notes on Cretaceous ammonites: 11. The phylogeny of the Desmocerataceae and Hoplitaceae. Ann. Mag. Nat. Hist. Ser. 12, 8:561-575.

Young, K., 1979. Early Cenomanian and late Albian (Cretaceous) ammonites, especially Lyelliceridae, of Texas and Mexico. Tex. Mem. Mus. Bull., 26.

Date of Initial Receipt: June 24, 1982

Date of Acceptance: March 30, 1983 


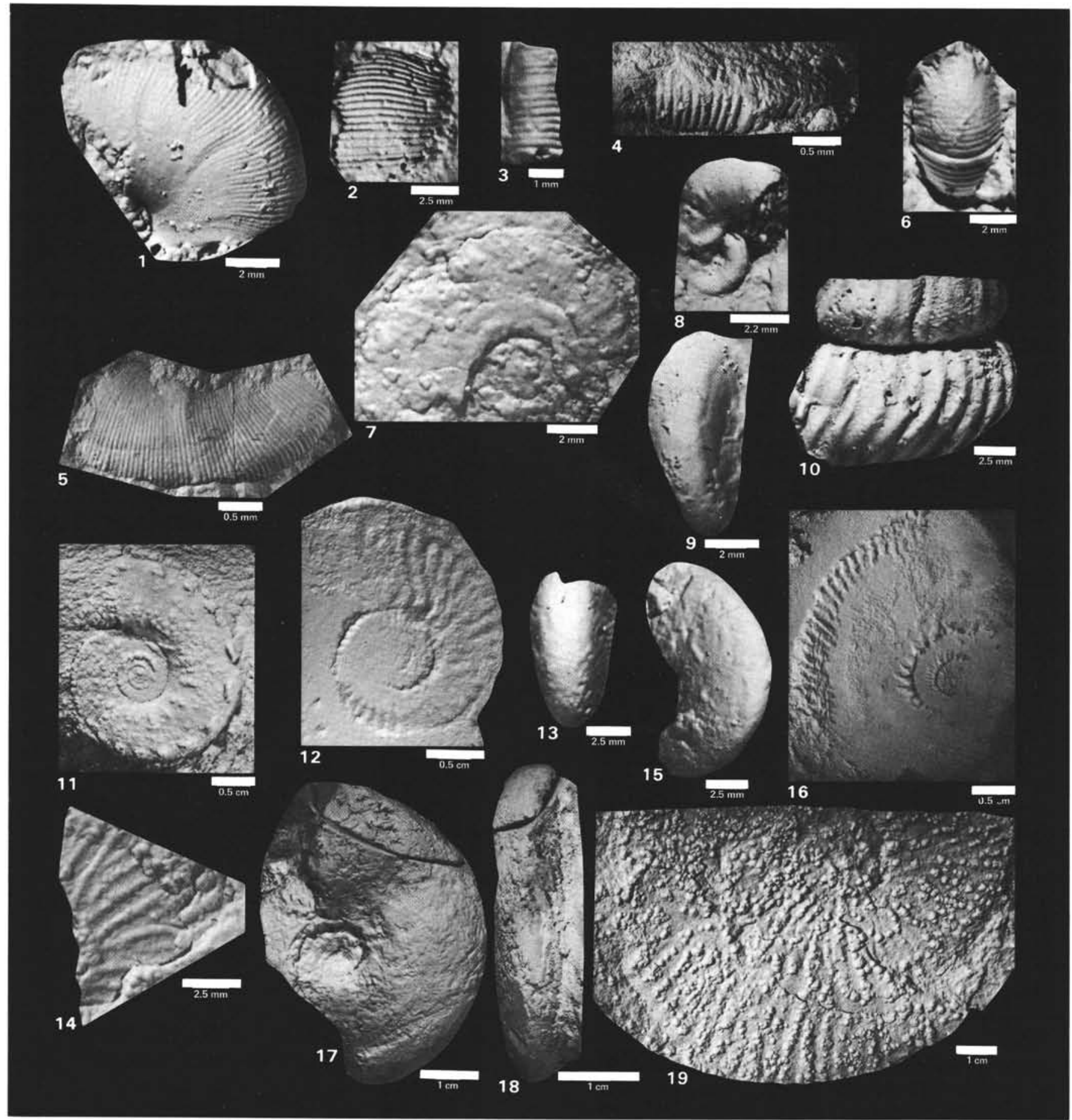

Plate 1. 1, 2, 5. Scaphites n. sp. aff. S. simplex Jukes-Browne, latest late Albian, Stoliczkaia dispar or Arrhaphoceras substuderi Subzones, (1) WSA-18423, from Sample 535-45,CC (5-8 cm), (2, 5) Sample 540-44-1, 73-78 cm (2, WSA-18434, 5, WSA-18416). 3. Stomohamites sp. cf. S. virgulatus (Brongniart, 1822), latest late Albian, Sample 535-45,CC (5-8 cm), WSA-18422. 4. Hamiticeras(?) sp. indet.; micropaleontologic data indicate a Hauterivian age, WSA-18432 is from Sample 535-60-21, 101-105 cm. 6. Holcodscid, genus and species indeterminate, Neocomian, WSA-18427 from Sample 537-4-1, 1-3 cm. 7, 11. Acompsoceras sp. juv., middle Cenomanian, (7) WSA-18420, from Sample 535-33-1, 35-37 cm, (11) WSA-18419, from Sample 535-31-1, 84-88 cm. 8. Scaphites sp. aff. S. simplex Jukes-Browne, latest late Albian, WSA-18425, from Sample 540-44-1, 20-22. 9. Lytocerid, genus and species indeterminate, latest Albian, WSA-18424, from Sample 535-45,CC (5-8 cm). 10. Turrilitoides sp. juv. cf. T. toucasi (Hébert and Munier-Chalmas), latest late Albian, Stoliczkaia dispar or Arrhaphoceras substuderi Subzones, WSA18421 , from Sample $540-44-2,0-8 \mathrm{~cm}$. 12, 16. Karakaschiceras sp. cf. $K$. victoriense (Imlay), early part of the late Valanginian, Collection Number UT-18418, from top of Section 535-74-3. 13. Hypophylloceras sp. indet., probably Neocomian on micropaleontologic evidence, WSA-18426, from Sample 537-4-1, 1-3 cm. 14. Neocomitine, genus and species indeterminate, probably Valanginian; WSA-18418, from Sample 535-73-3, 30-31 cm. 15, 17-18. Hypophylloceras sp. cf. H. guillantoni (Collignon), this species is long-ranged and little understood; micropaleontologic evidence indicates an age of Bedoulian; (15) WSA-18429, from Sample 535-47-2, 20-24 cm, (17-18) WSA-18430, from Sample 53546-1, 95-100 cm. 19. Neocomitine, genus and species indeterminate, micropaleontologic evidence suggests an age somewhere from late Valanginian to late Hauterivian, WSA-18417, from Sample 535-54-4, 67-68 cm. 